\title{
PLANOWANIE FINANSOWE W ZARZĄDZANIU DŁUGIEM SAMORZĄDOWYM - ANALIZA DYNAMICZNA NA PRZYKŁADZIE WOJEWÓDZTW SAMORZĄDOWYCH
}

\section{Wprowadzenie}

Wieloletnie planowanie finansowe stanowi niezbędny element zarządzania finansami jednostek samorządu terytorialnego. Wynika to między innymi z faktu wykonywania przez niewielu zadań publicznych wykraczających terminem realizacji poza jeden rok budżetowy - w tym w szczególności zadań o charakterze inwestycyjnym. Przygotowanie planu finansowego pozwala na wyznaczenie ram finansowych funkcjonowania jednostki w przyszłości. Ma to również szczególne znaczenie dla zarządzania długiem jednostki. Plan finansowy pozwala unaocznić władzom samorządowym oraz kredytodawcom obciążenie finansów jednostki spłatą długu oraz jego kosztami.

Wdrożenie przepisów ustawy o finansach publicznych z 2009 r. oznaczało konieczność przygotowania przez wszystkie jednostki samorządu terytorialnego w Polsce wieloletniej prognozy finansowej (WPF). Ponadto, począwszy od 2013 r., zbiorcze zestawienia WPF jednostek, gromadzone przez regionalne izby obrachunkowe, publikowane są przez Ministerstwo Finansów. W chwili przygotowywania niniejszego artykułu dostępne były dwa zestawienia WPF - od roku 2013 i 2014. Dostępność tych danych skłoniła autora do przeprowadzenia analizy zmian, jakie nastąpiły pomiędzy wybranymi kategoriami finansowymi prezentowanymi we wskazanych planach. W szczególności celem badania stało się wskazanie na znaczenie wieloletniego planowania w zarządzaniu długiem samorządowym poprzez analizę planowanych wielkości długu jednostek, jego obsługi oraz wypełniania limitów prawnych zadłużenia. Badanie przeprowadzono najpierw w sposób ogólny dla wszystkich jednostek, a następnie bardziej szczegółowo dla województw samorządowych. W pierwszej kolejności jednak przedstawiono rozważania na temat znaczenia WPF dla procesu zarządzania długiem samorządowym. 


\section{Znaczenie wieloletniego planowania finansowego w procesie zarządzanie długiem samorządowym}

Planowanie finansowe stanowi nieodzowny element zarządzania długiem jednostki. Zarządzanie długiem polega generalnie na badaniu i optymalizacji działań zmierzających do planowanego zaciągania i spłaty zobowiązań, zgodnie z potrzebami i możliwościami finansowymi jednostki z uwzględnieniem sytuacji na rynkach finansowych. Proces ten powinien uwzględniać przyjęty przez jednostkę model rozwoju oraz specyfikę jej gospodarki finansowej ${ }^{1}$. Kluczowy jest odpowiedni wybór formy i źródeł pozyskiwania funduszy. Podejmując decyzję dotyczącą rodzaju długu i konstrukcji zobowiązania, należy kierować się przede wszystkim kwestią kosztów jego obsługi. Konieczne jest również bieżące monitorowanie obsługi wcześniej zaciągniętych zobowiązań ${ }^{2}$ Niezbędne jest zatem wykorzystywanie w procesie zarządzania długiem wieloletnich planów finansowych. Plany te, determinowane sformułowaną przez jednostkę strategią rozwoju, odgrywają istotną rolę w procesie określania zdolności jednostki do finansowania zadań bieżących i inwestycyjnych - ze środków własnych i zewnętrznych. Stąd jednym z najważniejszych celów planowania finansowego jest zarządzanie długiem³.

Zgodnie z przepisami ustawy podstawę gospodarki finansowej jednostki samorządu terytorialnego stanowi budżet. Jest to plan finansowy sporządzany na rok budżetowy, określający wysokość dochodów i wydatków oraz przychodów i rozchodów jednostki, a także zobowiązań i należności. Jak wskazano wcześniej, z uwagi to, że wiele przedsięwzięć, w szczególności inwestycyjnych, terminem realizacji wykracza poza rok kalendarzowy, a zaciągane przez jednostki zobowiązania najczęściej mają charakter zdecydowanie dłuższy niż rok, niezbędne jest przygotowywanie planów finansowych na okres kilkuletni lub dłuższy.

Przed 2010 r. jednostki miały obowiązek formułowania prognoz zadłużenia. Procedura budżetowa obejmowała, oprócz przygotowania samego budżetu, sporządzenie prognozy długu i informacji o stanie mienia komunalnego ${ }^{4}$. Zatem plany wieloletnie, które dotyczyły takich kategorii finansowych jak dochody, wydatki, przychody

1 M. Bitner, Gmina na rynku kapitałowym. Podstawy zarządzania długiem komunalnym, Agencja Rozwoju Komunalnego, Warszawa 1999, s. 23; M. Poniatowicz, J.M. Salachna, D. Perło, Efektywne zarządzanie długiem w jednostce samorządu terytorialnego, Oficyna Wolters Kluwer, Warszawa 2010, s. 71.

2 K.S. Cichocki, Zarządzanie finansami i długiem samorządu terytorialnego w perspektywie wieloletniej, Polska Akademia Nauk, Instytut Badań Systemowych, Warszawa 2013, s. 51.

3 M. Jastrzębska, Zarządzanie długiem jednostek samorządu terytorialnego, Oficyna Wolters Kluwer, Warszawa 2009, s. 91.

4 Ustawa z dnia 30 czerwca 2005 r. o finansach publicznych, DzU nr 249, poz. 2104, art. 180. 
i rozchody, nie były obligatoryjne. Pomimo braku takiego obowiązku wiele jednostek sporządzało wieloletnie plany finansowe i inwestycyjne w celu zapewnienia ciągłości gospodarki finansowej i prowadzonych inwestycji. Ważność takich planów ustawodawca uznał w ustawie o finansach publicznych z 2009 r., wprowadzając obowiązek ich sporządzania pod nazwą wieloletniej prognozy finansowej, począwszy od $2010 \mathrm{r}$. na lata 2011+. W uchwale o WPF określa się planowane wielkości dochodów i wydatków, w podziale na bieżące i majątkowe, saldo budżetu, przychody i rozchody oraz wysokość długu na kolejny rok budżetowy i następne minimum trzy lata, jednak nie krócej niż do momentu, w którym jednostka planuje spłacić swoje zobowiązania. Ponadto w planie tym należy wykazać zdolność jednostki do wypełniania prawnych limitów długu, a także przedsięwzięcia związane przede wszystkim z realizacją projektów współfinansowanych ze środków unijnych oraz programów partnerstwa publiczno-prywatnego ${ }^{5}$.

Istotne znaczenie dla całego sektora samorządowego z punktu widzenia planowania finansowego stanowią dokumenty publikowane przez Ministerstwo Finansów. Przede wszystkim są to rozporządzenia ujednolicające formę WPF oraz wskazujące na sposób i termin jej przekazywania regionalnym izbom obrachunkowym i ministerstwu ${ }^{6}$. Dzięki takim zabiegom dostępne są publiczne dane, pozwalające na prowadzenie analiz przekrojowych. Ponadto rokrocznie publikowane są wytyczne dotyczące założeń makroekonomicznych przyjmowanych na potrzeby sporządzania WPF.

Przygotowywanie planów finansowych jest procesem niezwykle złożonym z uwagi na różnorodność prognozowanych kategorii finansowych oraz ich determinant. Poszczególne kategorie finansowe WPF charakteryzują się odmiennym sposobem i trudnością prognozowania ${ }^{7}$. Niektóre kategorie cechuje znaczna zmienność w czasie, a nawet nieprzewidywalność. Skomplikowane jest przykładowo prognozowanie wartości takich jak dochody, gdyż zależy ona tylko w części od decyzji władz samorządowych. W artykule WPF będzie rozpatrywana jako narządzie zarządzania długiem jednostki, stąd w następnej kolejności uwaga zostanie skupiona na specyfice planowania długu i jego obsługi.

Prognozowanie długu samorządowego należy rozpatrywać w dwóch kategoriach - zobowiązań już zaciągniętych i potencjalnych. Wydaje się, że z technicznego, planistycznego punktu widzenia zaplanowanie kwoty posiadanego długu i jego obsługi

\footnotetext{
5 Ustawa z dnia 27 sierpnia 2009 r. o finansach publicznych, DzU nr 157, poz. 1240, art. 226-227.

6 Rozporządzenie Ministra Finansów z dnia 10 stycznia 2013 r. w sprawie wieloletniej prognozy finansowej jednostki samorządu terytorialnego, DzU 2013, poz. 86.

7 Swoje rozważania na temat przygotowywania prognoz finansowych przez jednostki samorządu terytorialnego autor przedstawił szerzej w: Wieloletnie prognozy finansowe jednostek samorzadu terytorialnego a wytyczne Ministerstwa Finansów dotyczące ich założeń makroekonomicznych, w: Finanse w polityce makroekonomicznej państwa, red. S. Owsiak, Wydawnictwo UE w Krakowie, Kraków 2014, s. 177-188.
} 
jest relatywnie proste. Zasadniczo kwota zobowiązań oraz rozchody związane z jego spłatą wynikają z umów pomiędzy jednostką (dłużnikiem) a wierzycielami - dotyczy to umów pożyczki, kredytu czy dokumentów emisyjnych samorządowych papierów dłużnych. Zatem w myśl jednej z nadrzędnych zasad prognozowania „nie prognozuj tam, gdzie wiesz", kwoty zobowiązań i rozchodów z nimi związanych w WPF są pochodną umów z wierzycielami. Zmiany opisywanych wartości wymagałyby zmiany tych umów.

Kwestią, która wymaga nie tyle planowania, co rzeczywiście prognozowania (w wąskim tego słowa znaczeniu), jest kwota wydatków na obsługę długu - dotyczy to zarówno posiadanych zobowiązań, jak i tych potencjalnych. Wartość ta może bezpośrednio wynikać z umów, jeżeli oprocentowanie długu jest stałe. Jednakże w znaczącej większości dług samorządowy w Polsce oprocentowany jest w sposób zmienny, poprzez indeksację głównie w stosunku do WIBOR-u, dlatego też umowy regulują wydatki na obsługę długu de facto tylko w sposób pośredni. W takim przypadku można mówić o prognozowaniu tych wydatków, ponieważ niezbędna jest projekcja stawek rynku międzybankowego. Najczęściej stawki te prognozuje się na podstawie prognoz inflacji (podawanych przez Ministerstwo Finansów lub Narodowy Bank Polski), zakładając wysokie skorelowanie tych wielkości w czasie, a różnicę pomiędzy nimi (spread) za względnie stałą.

O rzeczywistym prognozowaniu wielkości długu i jego obsługi - w świetle polityki zarządzania długiem - można zatem mówić w przypadku zaciągania „nowych” zobowiązań lub zmiany warunków „starych”. Posiadany dług i wynikające z niego konsekwencje determinują kształt WPF, wskazując w szczególności na obciążenie przyszłych dochodów jego spłatą. Wykorzystanie WPF do celów polityki zarządzania długiem lokalnym powinno więc polegać na przygotowywaniu scenariuszy wielkości zadłużenia jednostki oraz jego obsługi i badaniu ich konsekwencji dla stanu gospodarki finansowej jednostki w przyszłości, z uwzględnieniem posiadanych dotychczas zobowiązań.

W świetle powyższych uwag można stwierdzić, że analiza historyczna WPF oraz sprawozdań z wykonania budżetów pozwala na zaobserwowanie efektów prowadzonej przez jednostki polityki zarządzania długiem. Badanie takie może dotyczyć takich kategorii, jak wielkość zadłużenia, termin jego spłaty, koszty jego obsługi i w końcu zdolność jednostki do wypełniania ustawowych limitów zadłużenia. Tego rodzaju badanie przeprowadzone zostanie w kolejnych punktach - najpierw ogólne dla wszystkich jednostek, a następnie bardziej szczegółowe na przykładzie województw samorządowych. 


\section{Dług samorządowy w Polsce w świetle wieloletnich prognoz finansowych na lata 2013+ i 2014+}

W punkcie 2 zbadano ogólne tendencje w zakresie planowania długu samorządowego w Polsce. Postanowiono przyjrzeć się relacjom pomiędzy wartościami planowanymi długu a wykonanymi, jak również zmianom planów zadłużenia prezentowanych w WPF sporządzanych krocząco. Relacje te (odpowiednie ilorazy) przedstawiono w tabeli 1 - dla roku 2013 stosunek pomiędzy wielkościami wykonanymi a planowanymi w WPF na lata 2013+, dla lat 2014-2016 stosunek pomiędzy wielkościami planowanymi w odrębnych WPF, sporządzonych odpowiednio na lata 2014+ i 2013+. Zadłużenie analizowano w kategoriach bezwzględnych oraz w relacji do dochodów ogółem i przedstawiono na tle dochodów ogółem, wydatków ogółem i wyniku budżetów.

Tabela 1. Zmiany w wielkościach zadłużenia samorządowego w WPF na tle wyników finansowych jednostek (w \%)

\begin{tabular}{|l|c|c|c|c|}
\hline \multirow{2}{*}{ Wyszczególnienie } & Wykonanie/plan wg WPF 2013+ & \multicolumn{3}{c|}{ Plan wg WPF 2014+/plan wg WPF 2013+ } \\
\cline { 2 - 5 } & 2013 & 2014 & 2015 & 2016 \\
\hline Dochody ogółem & 96,41 & 106,40 & 105,32 & 102,67 \\
\hline Wydatki ogółem & 91,43 & 114,29 & 107,51 & 103,81 \\
\hline Wynik & $-3,52$ & $-2938,62$ & 30,32 & 72,39 \\
\hline Zadłużenie & 97,08 & 108,07 & 113,58 & 117,78 \\
\hline Zadłużenie/dochody ogółem & 100,69 & 101,58 & 107,85 & 114,71 \\
\hline
\end{tabular}

Źródło: Obliczenia własne na podstawie: Wieloletnia prognoza finansowa jednostek samorzadu terytorialnego - na lata 2013 + i 2014+, Ministerstwo Finansów, www.finanse.mf.gov.pl; Sprawozdanie z działalności regionalnych izb obrachunkowych i wykonania budżetu przez jednostki samorzadu terytorialnego w 2013 roku, Krajowa Rada Regionalnych Izb Obrachunkowych, Warszawa 2014.

Występowanie kategorycznych trendów w kształtowaniu się wskazanych w tabeli 1 relacji będzie można potwierdzić z perspektywy kilku lat, niemniej jednak już na tym etapie zauważalne są pewne tendencje. W przypadku dochodów, wydatków i zadłużenia odnotowano w 2013 r. niższą wartość wykonania tych pozycji bilansowych niż planowanych. Z kolei relacje pomiędzy kroczącymi WPF wskazują na to, że wartości badanych kategorii finansowych są we wszystkich przypadkach większe w WPF na lata 2014+ niż we wcześniejszej WPF na lata 2013+.

W przypadku udziału długu w dochodach ogółem można odnotować znaczną trafność pomiędzy prognozą a wykonaniem w 2013 r., co wynikało z podobnego, niższego w stosunku do planu wykonania dochodów i długu. W latach prognozowanych 
z kolei widać znaczący wzrost badanej relacji, co oznacza, że jednostki ogólnie planują coraz to wyższy udział długu w dochodach ogółem. Obserwowalne jest to również z perspektywy wartości bezwzględnych - zwiększanie projekcji długu w kroczących po sobie WPF jest większe niż zwiększanie prognoz dochodów.

W odniesieniu do wyniku trudno stwierdzić występowanie długofalowych tendencji. W przypadku 2013 r. wartość ujemna wynika z wystąpienia nieznacznej nadwyżki w stosunku do planowanego, relatywnie dużego deficytu. W roku 2014 odnotować należy odwrotną sytuację: na ten rok zaplanowano w WPF na lata 2014+ znaczny deficyt w porównaniu z przewidywaną rok wcześniej nieznaczną nadwyżką. W kolejnych latach (2015 i 2016) odnotować można mniejszy optymizm samorządowych planistów - mimo że nadal według WPF na lata 2014+ planowana jest przeciętnie nadwyżka budżetowa, to nie jest ona tak wysoka jak w WPF na lata 2013+. Podsumowując analizy zmian planowanych wartości wyniku budżetów jednostek, należy stwierdzić, że im dalsza perspektywa czasowa, tym łatwiej władzom samorządowym przychodzi planowanie wyższych dochodów budżetowych.

Konkludując, wzrost zadłużenia samorządu przy jednoczesnym przewidywaniu pozytywnych wyników budżetu oznacza, jak się wydaje, chęć finansowania w przyszłości nowych inwestycji samorządowych za pomocą środków o charakterze zwrotnym. Może to wynikać z faktu, że jednostki spodziewają się wzrostu w najbliższym czasie wartości limitu indywidualnych wskaźników zadłużenia, zatem większej zdolności jednostek do zadłużenia się. Można przypuszczać, że jednostki postrzegają bieżącą sytuację finansową sektora pozytywnie, a przynajmniej odnotowują poprawę w porównaniu z ostatnim okresem, w którym indywidualne limity zadłużenia były relatywnie niskie, w szczególności w odniesieniu do wskaźników obowiązujących przed $2014 \mathrm{r}^{8}$

\section{Badanie zmian planowanych wielkości długu województw samorządowych i jego obsługi}

Przeprowadzone w poprzednim punkcie ogólne badanie zmian planów finansowych pod kątem zadłużenia samorządowego postanowiono uzupełnić bardziej szczegółową analizą przeprowadzoną dla województw samorządowych?

8 Szerzej na temat kształtowania się wartości limitów zadłużenia w opracowaniu autora: Nadwyżka operacyjna i dochody ze sprzedaży majątku jako podstawa limitowania zadlużenia jednostek samorządu terytorialnego w Polsce - analiza dynamiczna, „Zarządzanie i Finanse” cz. 3, nr 2, 2013, s. 454-464.

9 Pomimo dostępności danych badanie porównawcze WPF jest zajęciem żmudnym i czasochłonnym. Celem badania było zaś zbadanie całej zbiorowości jednostek jednorodnych zadaniowo, stąd wybór tego szczebla samorządu terytorialnego jako przedmiot analizy. 
Dokonana przez autora analiza porównawcza WPF sporządzonych przez województwa na lata 2013+ i 2014+ pozwoliła wskazać przede wszystkim na znaczące zmiany dotyczące zadłużenia. Dotyczyły one nie tylko samej kwoty zobowiązań, ale również wydatków na obsługę długu, przychodów i rozchodów - związanych odpowiednio ze spłatą lub zaciągnięciem zobowiązań, relacji długu do dochodów oraz wskaźników obrazujących spłatę długu i jej limit. Przykładowo, przeciętna różnica pomiędzy wartością wskaźnika długu do dochodów ogółem dla poszczególnych lat pomiędzy kroczącymi WPF wynosiła około kilkunastu punktów procentowych, a w niektórych latach przekraczała nawet 30 pkt. Okres badawczy obejmował lata, na które województwa sporządziły WPF, tj. począwszy od 2013 r., a skończywszy na 2036 r., na który istnieją najbardziej dalekosiężne plany województw mazowieckiego i zachodniopomorskiego. Jednakże najbardziej kluczowy jest okres do 2030 r., ponieważ w tym czasie wszystkie województwa planują posiadanie zobowiązań.

Rysunek 1. Odsetek województw samorządowych wykazujących wzrost planowanego poziomu długu i wydatków na jego obsługę

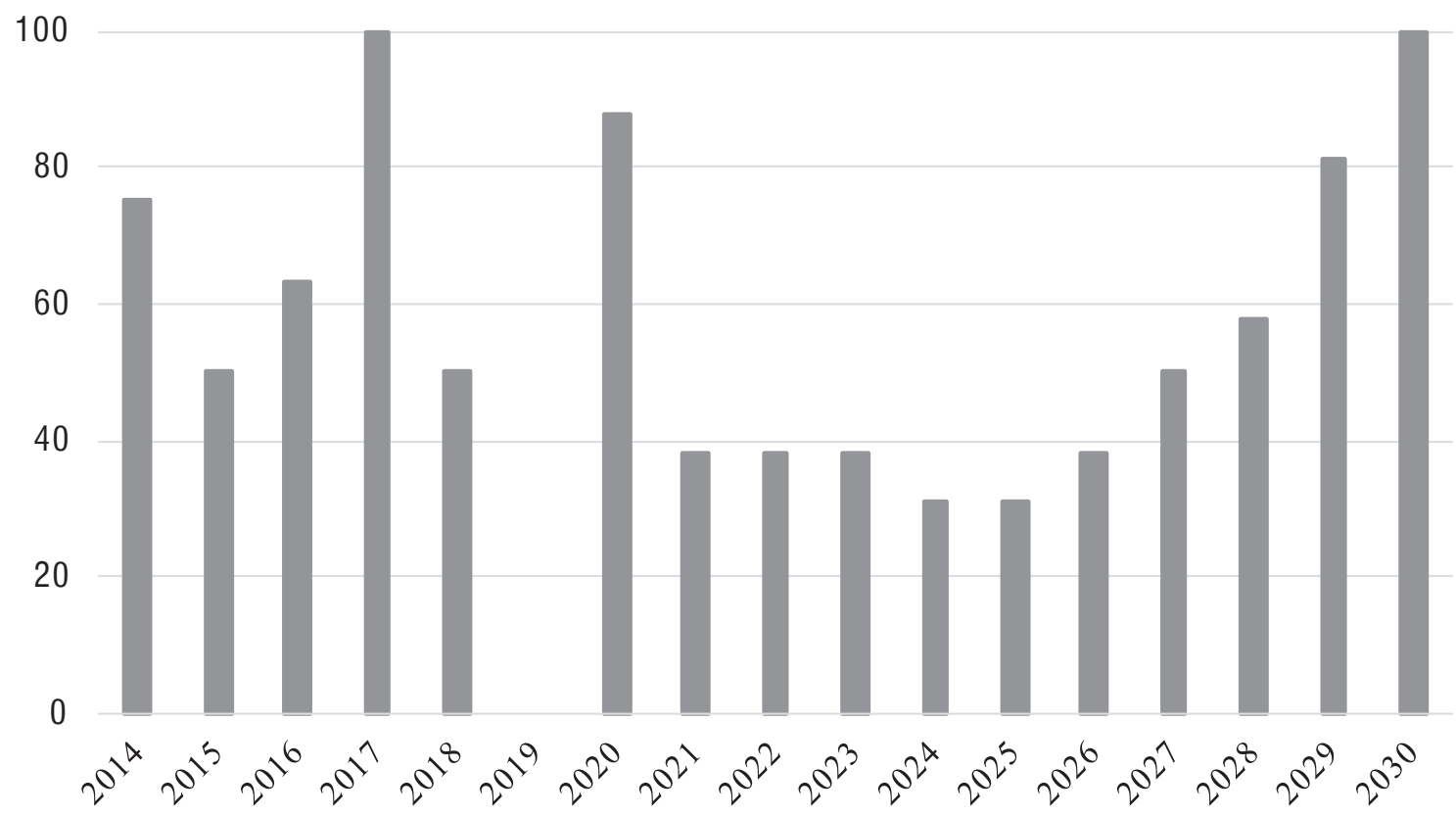

Źródło: Obliczenia własne na podstawie: Wieloletnia prognoza finansowa jednostek samorządu terytorialnego - na lata 2013+ i 2014+, Ministerstwo Finansów, www.finanse.mf.gov.pl

Nie sposób zaprezentować w niniejszym artykule wyników wszystkich przeprowadzonych obliczeń, dlatego postanowiono wybrać te najbardziej znaczące z punktu widzenia zarządzania długiem. W pierwszej kolejności (rys. 1) przedstawiono odsetek województw, które zwiększyły (krocząco) poziom planowanego długu i wydatków na jego obsługę w poszczególnych latach według WPF formułowanych na lata 
2013+ i 2014+. Analizowane kategorie finansowe zmieniały się w ten sam sposób, tzn. że jeżeli jednostka zwiększała swoje zobowiązania, to zawsze w parze odnotowywane były także większe wydatki na ich obsługę.

Warto zauważyć, że w pierwszych pięciu analizowanych latach przynajmniej co drugie województwo zaplanowało w WPF na lata 2014+ wyższy poziom długu i wydatków na jego obsługę niż w poprzednim planie finansowym, a w roku 2017 każde z nich. Z kolei w 2019 r. żadne z województw nie zwiększyło swojego długu. Wzrost długu odnotować można w większości badanych jednostek w 2020 r., a następnie dopiero po roku 2027. Wzrost odsetka bardziej zadłużonych województw (w stosunku do poprzednich planów finansowych) odnotować można zatem w pierwszych i ostatnich latach planu.

Kolejnym aspektem zarządzania długiem samorządowym, jaki rozpatrywano, jest zdolność województw do wypełniania ustawowych limitów zadłużenia. Od roku 2014 obowiązują nowe przepisy ograniczające w sposób indywidualny dług samorządowy. Regulacje uzależniają wielkość długu od posiadanej zdolności danej jednostki do jego spłaty. Kwota rozchodów związanych ze spłatą zobowiązań wraz z kwotą wydatków na obsługę długu w relacji do dochodów ogółem nie może w danym roku przekraczać indywidualnego limitu. Ten z kolei wyznaczany jest na podstawie średniej z trzech ostatnich lat wartości nadwyżki operacyjnej jednostki powiększonej o dochody ze sprzedaży majątku w relacji do jej dochodów ogółem ${ }^{10}$.

Na rysunku 2 przedstawiono, jak kształtowały się średnie arytmetyczne wskaźnika spłaty zobowiązań i indywidualnych limitów zadłużenia w poszczególnych latach według WFP na lata 2013+ i 2014+.

Znaczne rozbieżności pomiędzy wartościami analizowanych wskaźników można dostrzec szczególnie w pierwszych latach prognozy. Należy odnotować przede wszystkim wyraźnie wyższe wartości limitu w WPF na lata 2014+ niż średnio w poprzednim planie. Według tej prognozy przeciętnie województwa spełniają ustawowe wymogi dotyczące wskaźnika spłaty zobowiązań - z wyjątkiem lat 2017 i 2018. W przypadku WPF na lata 2013+ można było znaleźć więcej przypadków, w których województwa przeciętnie planowały przekroczenie indywidualnego limitu zadłużenia. Należy jednak mieć na uwadze, że w czasie przygotowywania tej WPF jednostki obowiązywały poprzednie regulacje zadłużenia, wskazujące, że obsługa długu w relacji do dochodów ogółem nie może przekraczać poziomu 15\%. Jak łatwo zauważyć, nowe przepisy w sposób bardziej restrykcyjny określają poziom długu samorządowego ${ }^{11}$.

10 Ustawa z dnia 27 sierpnia 2009 r. o finansach publicznych, DzU nr 157, poz. 1240, art. 243.

${ }^{11} \mathrm{Na}$ fakt wskazywano między innymi w: K. Marchewka-Bartkowiak, M. Wiśniewski, Indywidualny wskaźnik zadłużenia JST - ocena krytyczna i propozycje zmian, „Analizy BAS” nr 21(88), 2012. 
To mogło spowodować, że w WPF na lata 2014+ jednostki w sposób bardziej wiążący podeszły do kwestii spełniania nowych wymogów ustawowych.

Rysunek 2. Średnie planowane przez województwa samorządowe wartości wskaźnika spłaty długu i limitu zadłużenia (w \%)

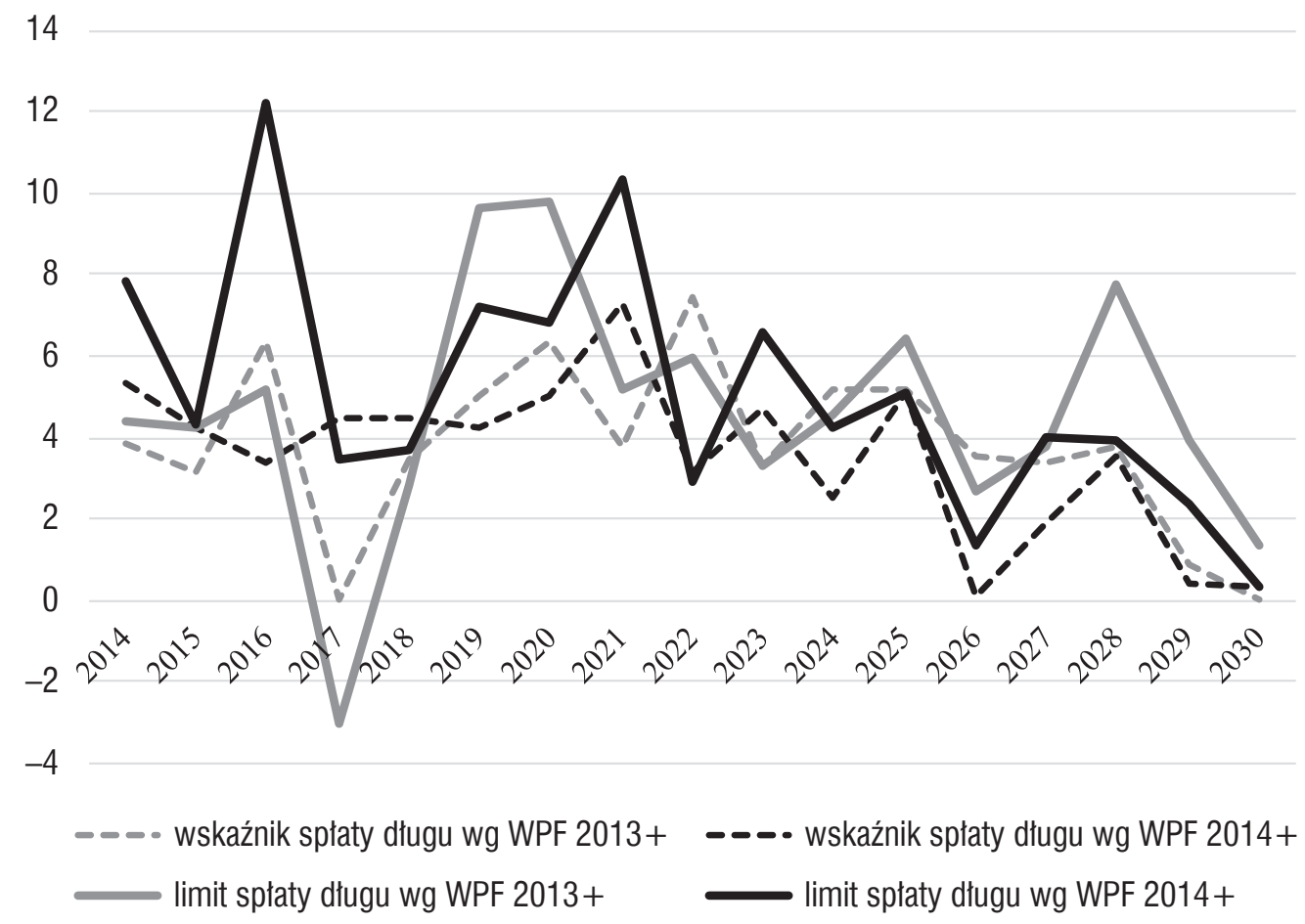

Źródło: Jak do rys. 1.

Warto zauważyć, że w przypadku bardzo odległych lat prognozy województwa wykazywały mniejszy optymizm w przypadku najnowszej WPF niż w przypadku poprzedniej. Zarówno wartość wskaźnika spłaty zobowiązań, jak i limitu we wcześniejszej prognozie były średnio większe niż w WPF dokonywanej rok później. Mogło to wynikać z faktu, że WPF jest nadal nowym narzędziem zarządzania finansami jednostek samorządu terytorialnego, a także z pewnej „łatwości” czy też „obojętności" władz w prognozowaniu kwot pozycji budżetowych, które staną się faktem za kilkanaście lub więcej lat.

\section{Podsumowanie}

Celem artykułu było wskazanie na rolę WPF w procesie zarządzania długiem jednostki samorządu terytorialnego. Rozważania teoretyczne uzupełniono przykładami 
stosowania WPF w praktyce. Porównano w szczególności, jak wyglądała realizacja planu w 2013 r., a także jak zmieniały się w kroczących prognozach kluczowe wielkości przyszłych budżetów jednostek samorządu terytorialnego. Badanie szczegółowe przeprowadzono dla województw samorządowych, analizując zmiany ich zobowiązań i kategorii z nimi związanych w następujących po sobie WPF.

Podjęte badania pozwoliły na wyciągnięcie następującego wniosku: plany finansowe wszystkich jednostek samorządu terytorialnego cechował swoisty optymizm, na co wskazywały ogólnie (w odniesieniu do całego sektora) niższe wartości wykonania niż planu w 2013 r. wartości długu i dochodów oraz wyższe wartości wskaźników spłaty zobowiązań i ich limitów dokonywane we wcześniejszych prognozach niż w późniejszych w przypadku przykładowych jednostek, którymi były województwa.

„Instytucję" wieloletniej prognozy finansowej należy uznać generalnie za słuszną i potrzebną, jednakże jej prawidłowe stosowanie i wykorzystywanie dla dobra finansów jednostki i przez to dla możliwości realizacji jej strategii rozwoju uzależnione jest od woli jej autorów i rzetelności prowadzonej przez nich polityki. Autor artykułu zwraca uwagę w szczególności na ciągłość polityki finansowej i inwestycyjnej jednostki, które są zasadniczo gwarantem stabilności jej gospodarki finansowej. Obiektywnie rzecz biorąc, niedopuszczalne są tak znaczące, a wskazane w artykule, zmiany planów finansowych pomiędzy WPF następującymi po sobie oraz tak znaczące różnice pomiędzy planem a wykonaniem poszczególnych wartości budżetowych. Dla budowania wiarygodności władz lokalnych, a przez to wspierania idei samorządności terytorialnej niezbędne jest zapewnienie trafności i ciągłości planów finansowych. Brak ich precyzji, a także niejednokrotne traktowanie WPF przez władze samorządowe jako „przykrego obowiązku” skutkuje - zdaniem autora - spadkiem zaufania do władzy samorządowej i narusza fundamenty społeczeństwa obywatelskiego.

\section{Literatura}

Bitner M., Gmina na rynku kapitałowym. Podstawy zarzadzania dtugiem komunalnym, Agencja Rozwoju Komunalnego, Warszawa 1999.

Cichocki K.S., Zarzadzanie finansami i długiem samorzadu terytorialnego w perspektywie wieloletniej, Polska Akademia Nauk, Instytut Badań Systemowych, Warszawa 2013.

Jastrzębska M., Zarządzanie długiem jednostek samorządu terytorialnego, Oficyna Wolters Kluwer, Warszawa 2009.

Marchewka-Bartkowiak K., Wiśniewski M., Indywidualny wskaźnik zadłużenia JST - ocena krytyczna i propozycje zmian, „Analizy BAS” nr 21(88), 2012. 
Poniatowicz M., Salachna J.M., Perło D., Efektywne zarządzanie długiem w jednostce samorząu terytorialnego, Oficyna Wolters Kluwer, Warszawa 2010.

Rozporządzenie Ministra Finansów z dnia 10 stycznia 2013 r. w sprawie wieloletniej prognozy finansowej jednostki samorządu terytorialnego, DzU 2013, poz. 86.

Sprawozdanie z działalności regionalnych izb obrachunkowych i wykonania budżetu przez jednostki samorzadu terytorialnego w 2013 roku, Krajowa Rada Regionalnych Izb Obrachunkowych, Warszawa 2014.

Ustawa z dnia 27 sierpnia 2009 r. o finansach publicznych, DzU nr 157, poz. 1240.

Ustawa z dnia 30 czerwca 2005 r. o finansach publicznych, DzU nr 249, poz. 2104.

Wieloletnia prognoza finansowa jednostek samorzadu terytorialnego - na lata 2013+ i 2014+, Ministerstwo Finansów, www.finanse.mf.gov.pl

Wiśniewski M., Nadwyżka operacyjna i dochody ze sprzedaży majątku jako podstawa limitowania zadłużenia jednostek samorzadu terytorialnego w Polsce - analiza dynamiczna, „Zarządzanie i Finanse” cz. 3, nr 2, 2013.

Wiśniewski M., Wieloletnie prognozy finansowe jednostek samorządu terytorialnego a wytyczne Ministerstwa Finansów dotyczace ich założeń makroekonomicznych, w: Finanse w polityce makroekonomicznej państwa, red. S. Owsiak, Wydawnictwo UE w Krakowie, Kraków 2014, s. 177-188.

\section{Financial planning in local government debt management. Dynamic analysis on the example of voivodships in Poland}

The article describes the role financial planning, in particular the role of multiannual financial forecasts, in the debt management process in the local government units. Theoretical and methodological considerations are supplemented by study of changes in budget categories related to local government debt, which took place between the multiannual financial forecasts prepared for the years 2013 and 2014. The analysis was performed for all units in general and more specifically for the voivodships. The article postulates that local authorities should ensure greater accuracy and continuity of their financial plans.

Keywords: local government, local government finance, local government debt, long-term financial planning 


\section{Planification financière dans la gestion de la dette publique locale. Analyse dynamique sur l'exemple des voïvodies en Pologne}

L’article décrit le rôle de la planification financière, en particulier le rôle des prévisions financières pluriannuelles, dans le processus de gestion de la dette dans les unités des collectivités locales. Des considérations théoriques et méthodologiques sont complétées par une étude des changements dans les catégories budgétaires liées à la dette des collectivités locales, qui a eu lieu dans les prévisions financières pluriannuelles préparées pour les années 2013 et 2014. L’analyse a été réalisée pour toutes les unités en général et plus particulièrement pour les voïvodies. L'article postule que les autorités locales devraient assurer une plus grande précision et la continuité de leurs plans financiers.

Mots-clés: administration locale, finances des collectivités locales, dette des collectivités locales, planification financière à long terme

\section{Финансовое планирование в управлении долгом субъектов местного самоуправления: динамический анализ на примере воеводств}

Статья представляет роль финансового планирования, в частности многолетнего финансового прогноза, в процессе управления долгом субъектов местного самоуправления. Теоретические и методологические соображения дополняются изучением изменений бюджетных категорий, касающихся долга субъектов местного самоуправления, которые произошли во время подготовки многолетних финансовых прогнозов 2013-2014 гг. Анализ охватывал субъекты местного самоуправления в целом и более подробно проводился на уровне воеводств. Статья заканчивается выводами. Постулируется, что местные органы власти должны обеспечить более большую точность и непрерывность финансовых планов субъектов местного самоуправления.

Ключевые слова: местное самоуправление, финансы местных органов власти, долг субъектов местного самоуправления, долгосрочное финансовое планирование 